\title{
Micro-Finance Operations and Socio-Economic Development of Nigeria Rural Communities
}

\author{
Ojua, Takim Asu (Ph.D) \\ L Lecturer, Sociology Department, University of Calabar,Nigeria. \\ Email:taojua2007@yahoo.com \\ Tiku, Oru Takim \\ L Lecturer, Sociology Department, University Of Calabar,Nigeria. \\ Agbor, Richard Atim \\ Holy Family Hospital Ikom, Cross River State
}

Doi:10.5901/mjss.2014.v5n23p742

\begin{abstract}
This paper focused on the role of Microfinance banks on the socio-economic development of rural communities in Nigeria. The operations of microfinance institutions date back to the pre - independence period in Nigeria when traditional thrift saving systems and activities of local people could not really handle the growing expansion and needs of the rural people and transformation. Also, the failure of conventional banking in Nigeria to meet the socio-economic complexities of the rural communities that consistently experiences rapid growth and changes as well as government desire to reach rural areas in development, gave rise to the emergence of microfinance institutions as a way of providing financial answers to the low income people so as to finance and improve their income generating activities. Key concepts such as conceptual overview and basic issues in microfinance, the role of microfinance banks in the socio-economic development of rural communities among others were analyzed. The paper adopted the demand following and supply leading hypothesis to support its argument. The paper concluded following its findings that small scale business men and women especially those operating within the rural communities are always confronted with the problem of financing their business; getting proper education to sustain the business and enlarge same. Therefore, the paper recommended that government should set up a more practical and result oriented monitoring and evaluation team to facilitate a cordial link between small scale business enterprises and microfinance banks in rural com munities.
\end{abstract}

Keywords: Microfinance, Rural, Communities, Socio-economic Development.

\section{Introduction}

Formal banking operations started in Nigeria before the nation's independence in different forms as a reaction to rural economic growth and social development. It was intensified during the post-independence era and to this day, rural banking operation services have become more pronounced with the provision of micro credit to rural dwellers intended to boost small and medium scale investment predominantly financed and supervised by commercial banks. Throughout the country, traditional group networks served as proprietors of financial exchange. They were led by traditional moneylenders who offered limited services and loans at disproportionately high interest rates. Nevertheless, it was documented that as early as 1936, the Government of Nigeria supported such exchanges as long as cooperative groups maintained their ordinance of coupling credit with regular and compulsory savings (OCWD, 2011; Haruna, 2007). The collapse of the barter system of exchange before now and subsequent monetization of the economy in recent times, have motivated the need for some form of mobilization of savings through either formal or informal method among rural community dwellers to boost socio-economic development. This has given credence to a type of banking transaction known as rotational saving which ultimately is now common in rural communities and urban centers. Glaringly and very fundamentally too, there was a great concern and gap by the different commercial banks in the country to handle the socio-economic needs of the rural communities and dwellers following the hard financial policies in individual or group assessing of loans and other facilities by the poorer people who are predominantly rural dwellers (Anyanwu, 2004; 
Olayiwola and Adeleye, 2005; Okafor, 2010).

According to the Organization of Communal Welfare Development (OCWD, 2011:1), and reacting to the diverse measures in handling the poverty condition in the rural areas, they asserts as thus:

\begin{abstract}
"A reconstitution of poverty led to a greater understanding of the diverse financial habits and needs of the poor and, more importantly, the discovery that the poor are able to save, and often do so through informal means due to a lack of formal opportunities to do so. Adding to this was a breakthrough in new lending technologies favourable to the microfinance sector. At the local level, the success of the Micro-Start Project highlighted the great potential of inclusive financial systems to alleviate poverty, induce socio-economic empowerment and catalyze sustainable development..."
\end{abstract}

The rural dwellers to a great extent suffer socioeconomic and environmental neglect and abandonment, poor and inaccessible roads, no infrastructural facilities, high rural-urban drift etc. and this make the subsistence farming productivity of no significance economically, as no yield could even upset the cost of productive investment. This therefore means they rotate or regenerate in social and economic status each year, hence, remain in poverty ridden condition yearly.

It is now common knowledge according to Egbe (2000) that the 1980s witnessed a rapid growth of commercial banking activities in many Nigerian rural communities where banking habits, culture, commitment and community development was poor if not non-existent. It is instructive to note that during this period, community funds among rural dwellers were hardly gathered for savings and loans to stimulate domestic investment. Suffice it to say that in rural communities, the rural business class hardly seeks formal institutional credits to improve their economic base. Every rural community runs after a rural cultural pattern that determines and influences the beliefs, attitudes and behaviours of these rural dwellers. Hence, the impact of the microfinance banks to determine its success or failure transcends financial provision to the rural dwellers to providing adequate small scale business knowledge for sustainability.

\title{
2. Methodology
}

The paper adopts principally a descriptive method of analysis of the general roles of the Microfinance Bank in rural Community Development as both a policy making and practice measures. This is quite necessary due to the increasing emphasis of rural development of communities and transformation. There is government need and policy formulation to grant the rural dwellers the desired developmental needs, but through the Microfinance sector of the Banking industry. The various community members therefore form rural associations and groups of cooperatives to gain access to these finances as part of assurance for the re-payment of these loans, as they don't have equilaterals or sureties for such transactions as individuals.

\section{Literature Review}

It is also worthwhile to note as stated in Central Bank of Nigeria 2005 policy document, that Microfinance policy, regulatory and supervisory framework for Nigeria is clear and meant to enhance the flow of financial services to Nigeria rural communities and encourage formal saving practices especially amongst rural dwellers. However, the Government of Nigeria tried to maintain a stronghold on financial activities by enacting a number of initiatives dedicated to rural development beginning in the 1970s. In particular, the National Agricultural and Cooperative Bank (NACB) and the Rural Banking Scheme (RBS) were founded in order to facilitate financial access to farmers. Government has in the past, initiated a series of publicly-financed micro-financed micro-rural credit projects and programs. Research shows that the microfinance sector in Nigeria has been experiencing immense growth upon the implementation of the UNDP funded Micro-Start Project in 1998 (OCWD, 2011). Since then, a number of factors have converged to contribute to this growth. Broadly, a considerable shift in global perceptions of poverty brought about a new international development paradigm characterized by localized, sustainable development through social enterprise. Moreover, a reconstitution of poverty led to a greater understanding of the diverse financial habits and needs of the poor and, more importantly, the discovery that the poor are able to save, and often do so through informal means due to a lack of formal opportunities to do so. Adding to this was a breakthrough in new lending technologies favourable to the microfinance sector. At the local level, the success of the Micro-Start Project highlighted the great potential of inclusive financial systems to alleviate poverty, induce socio-economic empowerment and catalyze sustainable development.

Despite the growth of the microfinance sector, a recent report from the Microfinance Information Exchange (MIX) found that Nigeria has the highest number of unbanked people in Africa, with over 80 million people lacking access to 
financial services. It is however noted that the increasing urbanization, exponential population growth and a rapidly expanding informal business sector add to the demand for access to financial services by micro and small enterprises (MSEs). The unequal distribution of institutions throughout the country and a skewed focus on urban markets pose a serious challenge to the ability to reach those at the bottom of the pyramid (OCWD, 2011; Todaro and Smith, 2011; Okafor, 2010).

The emergence of microfinance practice was prompted by the apparent failure of conventional development paradigms and approaches to achieve meaningful development. Microfinance banks seek to provide low income people with capital to finance their income generating activities. As a strategy, microfinance believes in the ability of the poor to meaningfully improve their conditions of living if they can access financial support on affordable terms. While microfinance practice like community-based savings or contribution schemes is not new in most communities, modern microfinance or what has become known as microfinance revolution on the other hand, is a creation of deliberate efforts at addressing poverty. The current form of practice grew out of development support agencies and governments desiring to improve productivity and conditions of livings of the rural farmers. This was the era when national development enterprise equated poverty with rural areas (Todaro and Smith, 2011). It was reasoned that rural dwellers or farmers were poor because they lacked access to funds. Banks' unwillingness to support small farmers has always been there. Small loans were disbursed to farmers in farmers' different cooperative societies, associations that are duly registered amongst other identified groups, but with very poor refunding or repayment rate and low interest, these forced these commercial banks to become disenchanted and uninterested in providing funds for the rural community development groups and associations.

The Nigeria economy, being capitalist oriented is driven by the principles and practices of the market economy. According to Anyanwu (2004), the willingness or inability of the formal financial institutions to provide financial services to the urban and rural poor, coupled with the sustainability of government sponsored development financial schemes contributed to the growth of private sector-led microfinance in Nigeria. Before the emergence of formal microfinance institution, informal microfinance activities flourished all over the country. Informal microfinance is provided by traditional groups that work together for the mutual benefits of their members. These groups provide savings and credit services to their members. The informal microfinance arrangements operate under different names (Anyanwu, 2004).

\section{Conceptual Overview and Basic Issues in Microfinance}

Research shows that the microfinance sector in Nigeria has been experiencing immense growth upon the implementation of the UNDP funded Micro-Start Project in 1998. The UNDP and UNCDF for instance collaborated to assist ASA Bangladesh to implement the Micro-Start Project in Nigeria. The first phase, from 1998 to 2004, provided technical assistance in line with international best practices to eight promising MFIs throughout the country. The target beneficiaries were the rural poor - people were excluded from formal financial systems before now. This exclusion according to Brau and Woller (2004) ranges from partial exclusion in developed countries to full or nearly full exclusion in less developed countries (LDCS). Due to lack of access to formal financial services, the poor have developed a wide variety of informal, community-based financial arrangement to meet their financial needs. In addition, over the last two decades, an increasing number of formal sector organizations (non-governmental, government and private) have been created for the purpose of meeting those same needs.

Microfinance has existed, although mostly in the shadows and unseen by casual observers, since the rise of formal financial systems. It has only been within the last four decades, however that serious global efforts have been made to formalize financial services provision to the poor. According to Brau and Woller (2004) that this process began in earnest around the mid-1980s and has since gathered an impressive momentum. Today, there are thousands of microfinance institutions (MFIs) providing financial services to an estimated $100-200$ million of the world's poor. What began as a grass root "movement" motivated largely by a development paradigm is evolving into a global industry. However, the rise of the microfinance industry represents a remarkable accomplishment taken within historical context. It has overturned established ideas of the poor as consumers of financial services, shattered stereotypes of the poor, and mobilized millions of dollars of "social investment" for the poor. Microfinance offered the potential to alleviate poverty while paying for itself and perhaps even turning a profit. This potential perhaps more than anything, accounts for the emergence of microfinance onto the global stage.

Conceptually, microfinance is the term that has come to refer generally to such informal and formal arrangements offering financial services to the poor. Haruna (2007) sees microfinance as the provision of credit, savings and other financial services to micro-entrepreneurs and low-income borrowers. It is considered distinct from the intermediation of the formal financial sector because it specifically targets low income people who lack access to credit for their income 
generation or production activities. Alilonu (2006) sees microfinance to the provision of financial services mainly savings and credit to the economically viable poor and low-income household without collateral. Microfinance is about providing finance services to the poor who are traditionally not served by the conventional financial institutions (CBN, 2005). Microfinance is an economic development strategy intended to provide financial services such as credit, savings, micro insurance, micro-leasing and payment services to poor and low income clients (Lemo, 2006).

There are several definitions to the conception of microfinance. It includes a broader range of services; mainly credit, savings opportunities, insurance and money transfers. It refers to loans, savings opportunities, insurance, money transfers and other financial products targeted to the poor. Micro-financing is not a new phenomenon in the Nigerian society as evidenced by cultural economic activities such as "Esusu", "AJO", "Adashi", "Otateje", etc. which were practiced to provide funds for producers in our rural communities (Akinboyo, 2007).

The effort of government in Nigeria is to modernize micro-financing in our rural and urban communities to improve the productive capacity of the rural and urban poor, enhance their economic standing which alleviates the level of poverty. According to Eluhiawe (2005), microfinance is often seen as the provision of thrift credit and other financial services and product in very small amounts to the poor to enable them to raise their income levels and improve their standard of living.

\section{Theoretical Orientation}

There are multiple theories that best help direct this paper, but more precisely the demand following and supply theory shall be adopted for this paper.

\subsection{The demand following and supply leading hypothetical construct}

The demand following financial theory refers to a kind of finance development that reacts positively to economic activities. The supply-leading finance on the other hand refers to the establishment of financial institutions in some areas before the demand for their service is considered. Demand following and supply leading financial theory is rooted in the fact that the financial system may be simultaneously growth inducing and growth induced. They emphasized that the most relevant issues for development is the efficiency with which the financial system provides financial institutions. They linked the supply of initiatives, enterprises and financial institution to be the creation, transformation and expansion of industries and other development oriented venture.

According to Hugh (Jhingan, 2004), although the two finance theory direction may interact at a point in time and overtime, there may be changes in prominence played by each type as the economy develops. The creation of the rural banking scheme arising from the Pious Okigbo's financial Review Committee in Nigeria (1976) was a direct response to the supply leading finance theory and the scheme was adopted by government to decongest the urban centers of banks and promote the development of banking habits, culture and service in rural areas.

The demand following finance theory explains the existence of financial institutions and their being established in urban centers where the demand for their services are high and are already intact or exist. In the supply leading finance theory, the challenges are to identify nascent firms, promote and support same to maturity in order to boost grassroots entrepreneurship. Financial institutions here stimulate effective entrepreneurship response for positive economic development.

This is anchored on the assumption that the growth of the financial sector is dependent on the growth and commercialization of other sectors. Also, it does not encourage savings, hence, it impedes development. Critics of the supply leading finance theory viable projects in the urban center that needs such funds to establish leading to the underutilization of potentials/resources.

This paper is anchored on the "demand following hypothesis". This is in view of the fact that most microfinance banks are sited in urban areas or semi-urban areas where there already exist the demand for financial services. And for these microfinance banks to function effectively, they should be demand driven and not supply leading. This goes on to show that more efforts must be put on ground for the establishment of these banks at the rural communities for more quicker and easier accessibility.

\section{The Role of Microfinance Banks in the Socio-Economic Development of Rural Communities}

In the past decades, creating access to financial services for small-scale businesses in the rural communities had been tasking. In response to these demands, microfinance banks have emerged and developed across the country. 
Ehijiamusoe (2008) opined that lending to micro-enterprises is no longer just a nice thing but is equally profitable. That microfinance has been acknowledged as an important instrument for meaningful development. Strategy for delivering financial services to the poor has become a feature of development agencies. It is worthwhile to note that regulatory agencies in most countries have formulated policies, regulatory and supervisory guidelines for microfinance practice basically to expand access to financial services to the poor or owners of micro enterprises.

Microfinance is usually conceived as the provision of small units of financial services to low income clients who are usually excluded from mainstream financial systems. Service users include artisans, small holder farmers, food processors, petty traders and other persons who operate micro-enterprises. A critical assessment in the practice according to Ehijiamusoe (2008) portrays microfinance as meaning more than delivery of small units of financial services. It goes beyond disbursement and collection of loans. It also refers to the flexible structures and processes by which affordable financial services are delivered to the owners of micro enterprises on a sustainable basis. Over the years, the scope of financial services of microfinance has been expanded to include savings, customer's loan, micro-leasing, microinsurance, money transfers and micro-investment services.

According to him, it is important to make some clarifications about microfinance practice. First, despite its poverty alleviation, microfinance is not charity. It is simply the provision opportunity for poor persons to access financial services on affordable terms. Second, microfinance in spite of the current emphasis is not a new creation especially for us in Africa. We have always had our "esusu" and "adashi" in communities across Nigeria. He further opined that modern microfinance practice has moved towards commercialization and promotion of innovations. For instance, the poor need financial services to build up assets, meet consumer needs, hedge against business risk and other emergencies. Microfinance recognizes the peculiar challenges of owners of micro and small enterprises especially in accessing financial services. In service delivery design, it takes into account the inability of the poor to provide tangible collateral required by formal financial institutions.

In the same vein, Akinboyo (2007) highlighted the roles of microfinance policy as it is the most effective poverty alleviation intervention tool worldwide;

$>$ It enables its clientele to become more self-reliant in their business endeavours especially in the face of mass unemployment in the country.

$>$ It helps to enhance the mobilization of local savings into productive ventures.

$>$ It helps to increase access to finance which will equally result in finances deepening.

$>$ It causes growth and improves income distribution of the populace.

Babangida (1990) believes that lack of funds have very often caused the collapse of small businesses and the extinction of ingenious ideas before they could be translated into reality. With microfinance banking, all such frustrations in recent times of our hardworking, devoted but under privilege masses would have come to an end. In the same vein, Okorie (1987) maintained that the rural poor are reported as mere dependents and are consumers of the trickle-down pay offs. That, one of the cruel ironies of rural poverty, is that although the rural poor play a major role in producing food, they are often largely ignored.

Using (2006) further reflecting on Modo (1997) position opined that a well known organization of this nature is the contribution groups known as "Osusu". In addition to this, clubs may operate a safe deposit from which members can borrow small sum of very easy agreeable terms. In many cases, such monies are usually used to buy rice, cow and even clothes at the end of the year or to commemorate any festival.

It is on record that different regimes in Nigeria have adopted a number of measures to extend economic development to the rural communities. Some of the notable approaches include; the Nigerian Agricultural and Cooperative Bank (NACB, 1992), Agriculture Credit Guarantee Scheme Fund (ACGSF, 1978), the People's Bank of Nigeria (PBN, 1989), the Rural Banking Program (RBP, 1977) was the outcome of the directives from Central Bank of Nigeria (CBN) requiring the commercial banks to open branches in rural areas. The program had a lending regulation which provides that not less than fifty percent of the deposit mobilized from the rural areas should be advanced to the rural borrowers. To set the ball rolling, the Central Bank of Nigeria (CBN) determined to boost the income base of rural community dwellers stepped into the management of Agricultural Credit Guarantee Scheme Fund (ACGSF). It is a scheme managed by the Central Bank of Nigeria (CBN). It provides guarantee cover to banks that give loans to the agricultural sector of the economy. This encourages the banks (including community banks/microfinance banks) to provide more funding to the farmers. Onugu (2002) described community/microfinance banks in Nigeria as catalyst for rural development in place of the rural branch banking program of the conventional banks. Babangida (1990) sees the fundamental concept of these banks as self-sustaining financial institutions owned and managed by the country, for the purpose of providing credit banking and other financial services to its members. In line with this postulation, Mabogunje (1991) opined that these banks as institutions representing the coalescence and modernization of two traditional 
institutions with which producers are very familiar.

Onugu (2002) sees the rural banking (microfinance) as having fared well in the provision of rural credit to a wide spectrum of community members engaged in economic activities. Appreciating this initiative, Okorie (1987) further ascertained the past attempts at providing for the credit needs of the rural dwellers had been through direct government initiatives. That this top-down approach alienated the people who such services were meant for. The community banking system adopts a bottom-up approach. Analyzing the reasons for the establishment of the community bank for rural development, Babangida (1989) according to Usang (2006) asserts that:

I am delighted to be associated with the launching of this special bank. As its name implies, the people's bank will, in both concept and operation, cater exclusively for the need of the ordinary Nigeria, especially the very poor in our society, who would normally not have access to loan assistance as currently operated with its policy of seeking to promote the welfare of our people especially the ordinary citizens, that this administration decided to establish this bank...

In his explanation of the benefits associated with community bank facilities, Babangida (1987) further said that those to benefit include privilege members of society who are involved in legitimate economic activities in both the urban and rural communities and who are sponsored by their various trade and professional groups. It is however expected that among many others, our road-side mechanics, self-employed technicians and artisan such as plumbers, vulcanizers and electricians, petty traders, livestock and poultry keepers, tailors, barbers, butchers, and all others who need financial assistance to improve their trade and economic wellbeing will be fully assisted by the scheme.

\section{Conclusion and Recommendations}

Small scale entrepreneurs especially those operating within the rural communities are always confronted with the problem of financing their business. In most cases, they resort to borrowing from money lenders, friends and even cooperative societies, perhaps with high interest rates, whereas, the microfinance banks should offer more appealing services. It has always been the opinion of government that microfinance banks should offer the low income group capital to stimulate their investment and boost their income, through this medium the poor could lead more meaningful life by improving on their living conditions. This paper proffers the following recommendations:

1. Government should set up a high level committee to aid in the deregulation of the activities and operations of the microfinance banks, especially in the areas of unifying of interests rates, deposit rates, credit subsidies and even in the mode of institutional lending.

2. Government should design a program to facilitate the issuance of loan facilities to indigenes with established skills in diverse business.

3. Government should set up a monitoring and evaluation team to facilitate a cordial link between small scale business enterprises and microfinance banks in rural communities.

4. The paper recommended among other things that women and youths within the ages of 20 to 30 year should be encouraged to source for funds from microfinance banks in setting up businesses.

5. Radio and television programs which centers on awareness on business opportunities and microfinance banks as viable sources of finance.

\section{References}

Akinboyo, O. L. (2007). Microfinance banks: Unlocking the potentials of micro-business activities of the Nigerian rural economy. Central Bank of Nigeria Bullion, 31 (1), $23-29$.

Alilonu, E. O. (2006). Overview of the New Nigeria Microfinance policy frameworks for microfinance banks. Paper presented at the National Workshop on Empowerment through microfinance, Calabar, July 8.

Anyanwu, C. M. (2004). Microfinance institutions in Nigeria: Policy, Practice and potentials. Paper presented at the G24 workshop on constraints to growth in Sub-Sahara Africa, Pretoria, South Africa, November 12.

Babangida, I. B. (1989). The People's Bank of Nigeria: Its aims and objectives. An address delivered on the occasion of the commissioning of the People's Bank of Nigerian, Ajegunle, Lagos, October 3.

Brau, J. C. \& Woller, G. M. (2004). Microfinance: A comprehensive review of the existing literature. Journal of Entrepreneurial Finance and Business Ventures, 9 (1), 1 - 34.

Egbe, O. O. (2000). Influence of rural banking on community development in Obubra Local Government Area of Cross River State. Unpublished HND Project, The Polytechnic, Calabar, Nigeria.

Ehigiamusoe, G. (2008). The role of microfinance institutions in the economic development of Nigeria. Central Bank of Nigeria Bullion, 
$31(1), 22-28$.

Eluhaiwe, P. N. (2005). Poverty reduction through micro-financing: The case of India. Central Bank of Nigeria Bullion, 30 (3), 37 - 42. Jhingan, M. L. (2004). Monetary Economics. New Delhi: Vrindha Publishers.

Okafor, K. J. (2010). Rural Community Development in Nigeria. Enugu: East-wing Publishers Ltd.

Okorie, A. (1987). Agricultural credit policies in Nigeria: A review of achievement, problems and prospects. In U. Fuein, A. Okorie and M. O. Iyere (Eds.) Reading in Agriculture. Nsukka: University of Nigeria Press, 126 - 138.

Olayiwola, M. \& Adeleye, A. (2005). Rural Infrastructure development in Nigeria between 1960 - 1990: Problems and Challenges. Journal of Social Sciences, 11 (2).

Onugu, C. U. (2002). Key issues in the concept and operations of community banks in Nigeria: Implications for rural development. Nigeria Journal of Rural Sociology, 4 (1), $43-57$.

Todaro, M. P. \& Smith, S. C. (2011). Economic Development (11th ed.). Essex: Pearson Educational Ltd.

Usin, E. E. (2006). Rural development in Nigeria: A critical appraisal of the role of Cross River State community-based poverty reduction agency and its sustainability. Nigeria Journal of Rural Sociology, 7 (2), 33 - 48. 